\title{
Actin-Like Protein 6B
}

National Cancer Institute

\section{Source}

National Cancer Institute. Actin-Like Protein 6B. NCI Thesaurus. Code C157278.

Actin-like protein 6B (426 aa, $\sim 47 \mathrm{kDa}$ ) is encoded by the human ACT L6B gene. This protein is involved in chromatin remodeling and transcriptional regulation. 